\title{
Antiproliferative, antimicrobial, and antioxidant activity of Lavandula angustifolia Mill. essential oil
}

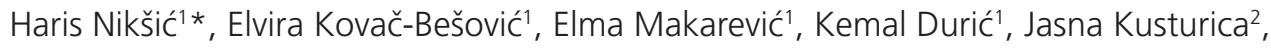 \\ Samija Muratovic ${ }^{1}$
}

${ }^{1}$ Department of Pharmacognosy, Faculty of Pharmacy University of Sarajevo, Sarajevo, Bosnia and Herzegovina, ${ }^{2}$ Department of Pharmacology, Faculty of Medicine University of Sarajevo, Bosnia and Herzegovina

\begin{abstract}
Introduction: We studied the chemical composition and antimicrobial, antioxidant, and antiproliferative activities of essential oils from flowers of Lavandula angustifolia grown in Southern Bosnia and Herzegovina.

Methods: The chemical profile of essential oil was evaluated by means of gas chromatography-mass spectrometry. Antimicrobial activity was tested against six bacterial strains. The antioxidant activity by the 1,1-diphenyl-2-picrylhydrazyl (DPPH) test and the antiproliferative activity against three human cancer cell lines, MCF-7, NCl-H460, and MOLT-4, were investigated using 3-(4,5-dimethylthiazol-2-Yl)-2,5-diphenyltetrazolium bromide tests.
\end{abstract}

Results: In L. angustifolia essential oil, monoterpene alcohols were the most represented class of volatiles $(51.8 \%)$, including linalool, lavandulol, and terpinen-4-ol, $\alpha$-terpineol as the major components, followed by monoterpene esters (22.6\%). The most important antibacterial activity of essential oil was expressed on Gram-negative strains. Investigated essential oil was able to reduce DPPH radicals into the neutral DPPH-H form (inhibitory concentration $50 \%\left[I_{50}\right]=0.421 \mathrm{mg} / \mathrm{ml}$ ), and this activity was dose dependent. The essential oil showed significant antiproliferative activity against three cancer cell lines, MOLT-4, MCF-7, and $\mathrm{NCl}-\mathrm{H} 460$ cells, with $\mathrm{IC}_{50}$ values of 17,94 , and $97 \mu \mathrm{g} / \mathrm{ml}$, respectively. The result of the antiproliferative assay indicates that MOLT-4 cell line was the most sensitive to investigated essential oil.

Conclusion: The results revealed that $L$. angustifolia essential oil may be important growth inhibitor against the microbes studied. It also possesses significant antioxidant activity and demonstrated excellent antiproliferative activity against MOLT-4 cells.

Keywords: Lavandula angustifolia; essential oil; antimicrobial; antioxidant; antiproliferative; gas chromatography-mass spectrometry analysis

\footnotetext{
*Corresponding author: Haris Nikšić,

Faculty of Pharmacy University of Sarajevo, Zmaja od Bosne 8,

71000 Sarajevo, Bosnia and Herzegovina.

E-mail: harisniksic@gmail.com
}

Submitted: 22 February 2017/Accepted: 27 March 2017

DOI: https://doi.org/10.17532/jhsci.2017.412

\section{INTRODUCTION}

Cancer is a complex disease that can affect any part of the body. It is the second most frequent cause of mortality, with about 8.2 million deaths and 14 million new cases annually, worldwide (1). It is expected that annual cancer death rate will continue to increase, reaching 11.4 million in 2030 (2). 
The study of natural products has until today been the single most successful strategy for the discovery of new medicines used in anticancer therapy, and more than two-thirds of the drugs used in cancer treatment come directly from natural products or are developed using knowledge gained from the activity of their ingredients (3). Essential oils, secondary metabolites of plants, are mixtures of chemical substances mainly terpenes. Terpenes are considered as valuable natural source of pharmacologically active compounds that can be used in the treatment of various diseases (4).

The constituents of essential oils are classified as terpene hydrocarbons, distinct in monoterpenes (C10), sesquiterpenes (C15), and diterpenes (C20). Monoterpenes are the most abundant constituents, and often, the antitumor activity of essential oils has been related to their presence in the phytocomplex. Linalyl acetate, alpha-terpineol, and camphor in association with linalyl acetate, alpha-terpineol, and camphor caused inhibition of the growth of the human cancer cell lines $(4,5)$.

Reactive oxygen species (ROS) and oxidative stress play an important role in the etiology and progression of major human degenerative diseases. Nowadays, evidence supports that antioxidant substances in some essential oils as Lavandula angustifolia Mill. essential oil can prevent oxidative damage of cells and ROS-induced diseases by reacting with free radicals, scavenging free radicals. In addition, essential oils are potentially useful sources of antimicrobial compounds. Numerous studies have been published on the antimicrobial activities of plant compounds against many different types of pathogens. Antioxidant, antimicrobial, and antiproliferative activity of essential oils cannot be attributed only to major components, but the interaction of all constituents present in the essential oil plays an important role $(4,6)$.

L. angustifolia Mill. belongs to the family Lamiaceae, genus Lavandula. It contains species with the essential oils of a high economic value, so it represents the most important genus in the family Lamiaceae. In Balkan region, the lavender essential oil is conventionally used for the treatment of antibacterial and antifungal infections, flatulence, depression, and anxiety (7). Although L. angustifolia is commercially cultivated in many regions of the world, it is wild species in Balkans. The ecological conditions of different countries may influence the chemical profile of the plant materials because some compounds may be accumulated at a particular period in response to environmental conditions. Essential oils collected from different countries at different seasons comprise different chemical compositions and thus may exhibit different biological activities (8). This prompted us to investigate the chemical profile of lavender essential oil native to Bosnia and Herzegovina and determine its biological activities. There are no previous studies related to examination (antiproliferative, antioxidative, and antimicrobial activities) of the essential oils of $L$. angustifolia from the south of Bosnia and Herzegovina and South Balkan region. Thus, the aim of the present study was to determine the chemical constituents and evaluate the antiproliferative, antioxidant, and antibacterial activities of the essential oil extracted from L. angustifolia Mill. growing wild in Bosnia and Herzegovina.

\section{METHODS}

\section{Plant material and isolation of the essential oil}

The flowering aerial part of wild growing plant of L. angustifolia Mill. was collected in June 2015 in the south region of Bosnia and Herzegovina (location: Latitude N4341'30.14"; Longitude E17 $\left.50^{\prime} 12.37^{\prime \prime}\right)$. Voucher specimen of the collected plant material No.114/15 was confirmed by Prof. Samir Đug and deposited at the Herbarium of the Department of Biology Faculty of Sciences, University of Sarajevo. Only the flowers were used for the preparation of the essential oil. The essential oil was recovered by hydrodistillation according to the European Pharmacopoeia 7 edition (9), using Clevenger apparatus (Klaus Hofmann GmbH, Germany), using $20 \mathrm{~g}$ of dry material and $400 \mathrm{ml}$ of water. The duration of the hydrodistillation was $2.5 \mathrm{~h}$, and the resulting oil was dried over anhydrous sodium sulfate and stored at $4^{\circ} \mathrm{C}$ in a dark glass vial. The quantity of the predestilated essential oils was determined volumetrically. The essential oil, as well as stock solutions, was kept in dark at $4^{\circ} \mathrm{C}$. 


\section{Essential oil analysis}

Qualitative and quantitative analyses of the essential oils were carried out using a gas chromatography/mass spectrometry system (GC-MS, Thermo Scientific, Palo Alto, USA, Thermo Scientific DSQ II Series Dual-Stage Quadrupole $\mathrm{GC} / \mathrm{MS}$ ) at electron energy $=70 \mathrm{eV}$. As a carrier gas, helium $(1 \mathrm{ml} / \mathrm{min})$ was used. The capillary columns (ZB-5MS $30 \mathrm{~m} \times 0.25 \mathrm{~mm}$; film thickness $0.25 \mu \mathrm{m}$ Phenomenex, Torrance, USA) were used. The temperature programs were $60-250^{\circ} \mathrm{C}$ at a rate of $4^{\circ} \mathrm{C} /$ minutes until $250^{\circ} \mathrm{C}$, respectively, with split ratio, 1:50. Injector and transfer line were set to $260^{\circ} \mathrm{C}$ and $270^{\circ} \mathrm{C}$, respectively. Coelution and MS analysis based on the identification of the individual compounds, and the comparison of their relative retention times (RTs) with those of the reference samples was performed. Oil constituents were identified by comparison of their retention indices with those of the literature, determined in relation to a homologous series of n-alkanes (C8-C20) under the same operating conditions. For the components, mostly sesquiterpenes and aliphatic compounds, for which reference substances were not available, the identification was performed by matching their $\mathrm{RT}$ and mass spectra with those obtained from the authentic samples and/or the National Institute of Standards and Technology, known as the National Bureau of Standards, Wiley libraries spectra as well as with literature data (10). Software AMDIS version 2.62 was used.

\section{Antibacterial activity}

Antimicrobial activity of essential oil, isolated from L. angustifolia was carried out according to the diffusion method we used in our earlier study (11). A collection of six test organisms, including three Gram-positive and three Gram-negative bacterial strains, was used. The groups included five organisms of American Type of Culture Collection (ATCC) and one organism of National Collection of Type Cultures. The source of the bacterial strains is shown in Table 1. All test organisms were stored at $+4^{\circ} \mathrm{C}$ on Mueller-Hinton agar slants, subcultured every 2 weeks and checked for purity. Antibiotics which are therapeutically important in treating infections caused by these microorganisms were used as comparative substances (as positive control): ciprofloxacin for the evaluation of antimicrobial activity of Pseudomonas aeruginosa, penicillin G for Bacillus subtilis, gentamicin for Staphylococcus aureus and Staphylococcus epidermidis, and tetracycline for Escherichia coli and Salmonella enterica subsp. enterica serotype ABONY. All samples were applied as solution in n-hexane. The effect of the solvent (n-hexane) on the microbial growth was also analyzed. On the surface of the agar, the $6 \mathrm{~mm}$ holes in diameter were punched. One hundred microliters of the tested essential oils $(5 \%, 1 \%, 0.5 \%$, and $0.1 \%$ solutions in $\mathrm{n}$-hexane) was applied to the holes. The plates were incubated overnight at $37^{\circ} \mathrm{C}$, and the diameter of the resulting zone of inhibition was measured. The evaluation of the antibacterial activities of the essential oils was carried out in three repetitions.

\section{Antioxidant activity}

\section{Chemicals and instruments}

1,1-diphenyl-2-picrylhydrazyl (DPPH•) as free radical form (90\% purity) and 6-hydroxy-2,5,7,8 tetramethylchroman-2-carboxylic acid (Trolox) were obtained from Sigma-Aldrich, Quimica (Alcobendas, Spain). N-hexane was provided by Merck (Mollet del Valle's, Spain). All reagents were of analytical grade. Double distilled water (Millipore Co.) was used throughout. Absorbance measurements were recorded on ultraviolet/visible mini-1240 spectrophotometer (Shimadzu, Japan).

\section{DPPH method}

A hexane solution $(90 \mu \mathrm{M})$ of the radical DPPH• was prepared daily and protected from light. Absorbance was recorded to check the stability of the radical throughout the time of analysis. Stock solution $(2 \mathrm{ml})$ of essential oil was mixed with $90 \mu \mathrm{M}$ DPPH $(2 \mathrm{ml})$ solution. Absorbance at $515 \mathrm{~nm}$ was recorded after reaction reaches an equilibrium at about 95 minutes. The blank reference cuvette contained hexane. Stock solutions were diluted to $10 \mathrm{ml}$ with $\mathrm{n}$-hexane to yield the concentrations of $0.12,0.249,0.495,0.617$, and $0.74 \mathrm{mg} / \mathrm{ml}$, respectively. Absorbance intensity of DPPH at wavelength $515 \mathrm{~nm}$ was measured in the test solutions that were contained $2 \mathrm{ml}$ of $90 \mu \mathrm{M}$ DPPH solution and $2 \mathrm{ml}$ of tested dilutions of essential oil (from 0.12 to $0.74 \mathrm{mg} / \mathrm{ml}$ ). 
TABLE 1. Antibacterial activity (inhibition zone measured in $\mathrm{mm}$, including hole $6 \mathrm{~mm}$ in diameter) of essential oils of $L$. angustifolia

\begin{tabular}{llccccl}
\hline Source & Organism & $5 \%$ & $1 \%$ & $0.5 \%$ & $0.1 \%$ & Positive control \\
\hline ATCC 6633 & Bacillus subtilis & $16 \pm 0.5^{*}$ & $12 \pm 0.8$ & $13 \pm 0.5$ & - & $21 \pm 2$ penicilin \\
ATCC 6538 & Staphylococcus aureus & $30 \pm 1$ & $19 \pm 0.5$ & $22 \pm 1$ & $11 \pm 0$ & $17 \pm 0$ gentamycine \\
ATCC 11228 & Staphylococcus epidermidis & $18 \pm 1$ & $15 \pm 0.5$ & $12 \pm 0.5$ & $11 \pm 0.7$ & $23.5 \pm 0.5$ gentamycine \\
ATCC 8739 & Escherichia coli & - & - & - & - & $18.5 \pm 0.5$ tetracycline \\
ATCC 9027 & Pseudomonas aeruginosa & $30 \pm 0.4$ & $11 \pm 0.5$ & $15 \pm 0$ & - & $40.5 \pm 0.5$ ciprofloxacine \\
NCTC 6017 & Salmonella enterica subsp.enterica & $16 \pm 0.5$ & $15 \pm 0.5$ & $18 \pm 0.6$ & - & $20 \pm 0$ tetracycline \\
& serotype ABONY & & & & & \\
\hline
\end{tabular}

*The values shown represent the average of three determinations \pm standard deviations. All essential oils were diluted in n-hexane (solvent expressed no activity on bacterial growth). L. angustifolia: Lavanda angustifolia

Absorbencies intensity of the test solutions and the blank (with same chemicals, except sample) were measured at the 0 minute and at the time when the steady state of the reaction between DPPH and analyzed compound was reached. 0.1 M Trolox was used as positive control. For each sample, three replicates were recorded. Free radical scavenging capacity in percent (RSC [\%]) was calculated by following Equation [1]:

RSC $(\%)=100 *\left(\mathrm{~A}_{\text {Blank }}-\mathrm{A}_{\text {Sample }}\right) / \mathrm{A}_{\text {Blank }}$

From the obtained RSC values, the effective concentration $50 \%\left(\mathrm{EC}_{50}\right)$ values, which represent the concentration of the essential oil that caused 50\% neutralization, were determined by linear regression analysis. The antiradical efficiency was calculated considering the $\mathrm{EC}_{50}$ value and the necessary time to reach the $\mathrm{EC}_{50}\left(\mathrm{TEC}_{50}\right)$, according to the following equation [2] $(11,12)$.

$$
\mathrm{AE}=\frac{2}{\mathrm{EC}_{50} * \mathrm{TEC}_{50}}
$$

\section{Antiproliferative activity}

The antiproliferative activity of the oil was determined using 3-(4,5-dimethylthiazol-2-Yl)-2,5-diphenyltetrazolium bromide (MTT) assay. The purpose of this study was to obtain the specific activity profile of lavender essential oil by the determination of the activity at different concentrations in an appropriately selected cell panel. For this purpose, well-characterized cell lines with regard to tumor type, genotype, proliferation rates, growth characteristics (solid and hematological), and general drug sensitivity and resistance were used (three cell lines found in the National Cancer Institute cell line screen). A known antitumor compound doxorubicin was used as a control, referent compound, in parallel with the tested compounds (13).

\section{Cell lines}

The experiments were carried out on three human tumor cell lines: MCF7 (breast adenocarcinoma, ATCC $^{\oplus} \mathrm{HTB}^{2} 2^{\mathrm{TM}}$ ), NCI-H460 (lung carcinoma, large cell lung cancer (ATCC ${ }^{\circledast} \mathrm{HTB}^{-177^{\mathrm{TM}}}$ ), and MOLT-4 (acute lymphoblastic leukemia ATCC ${ }^{\circledR}$ CRL-1582 $\left.2^{\text {TM }}\right)$.

\section{Cell culturing and proliferation assay}

The cells were cultured as monolayers (MCF7 and NCI-H460) or suspension (MOLT-4) and maintained in RPMI 1640 medium, supplemented with $10 \%$ fetal bovine serum, $2 \mathrm{mM}$ L-glutamine, $100 \mathrm{U} / \mathrm{ml}$ penicillin, and $100 \mu \mathrm{g} / \mathrm{ml}$ streptomycin in a humidified atmosphere with $5 \% \mathrm{CO}_{2}$ at $37^{\circ} \mathrm{C}$.

Results were analyzed according to a slightly modified protocol used at the National Cancer Institute (14). The cell lines were inoculated in parallel to a series of standard 96-well microtiter plates on day 0 , at $1.2 \times$ 104 cells/ml (H460), $3 \times 104$ cells/ml (MCF7), or $1 \times 105$ cells/ml (MOLT- 4 ), depending on the doubling times of specific cell line. Test substances were then added at 5, 10, 50,100, 500, or $1000 \mu \mathrm{g} / \mathrm{ml}$ concentrations and incubated for a further 72 hours. Doxorubicin was used in parallel as a control, reference compound, and was added in five 10 -fold dilutions $\left(10^{-10}\right.$ to $\left.10^{-6} \mathrm{M}\right)$. Working dilutions were freshly prepared on the day of testing. The solvent dimethylsulfoxide (DMSO) was also tested for eventual inhibitory activity by adjusting its concentration to be the same as in working concentrations; its maximal concentration never exceeded $0.1 \%$. After 72 hours of incubation, the cell growth rate was evaluated by performing the MTT assay, which detects 
dehydrogenase activity in viable cells. The MTT cell proliferation assay is a colorimetric assay system, which measures the reduction of a tetrazolium component (MTT) into an insoluble formazan product by the mitochondria of viable cells. For this purpose, the substance-treated medium was discarded and MTT was added to each well at a concentration of $20 \mu \mathrm{g} / 40 \mu \mathrm{l}$. After four hours of incubation, the precipitates were dissolved in $160 \mu \mathrm{l}$ of DMSO. The absorbance (A) was measured on a microplate reader at $570 \mathrm{~nm}$. The absorbance is directly proportional to the cell viability. The percentage of growth (PG) of the cell lines was calculated according to one or the other of the following two expressions:

If $\left(A_{\text {test }}-A_{\text {tzero }}\right) \geq 0$, then

$P G=100 \times\left(A_{\text {test }}-A_{\text {tzero }}\right) /\left(A_{\text {cont }}-A_{\text {tzero }}\right)$

If $\left(A_{\text {test }}-A_{\text {tzero }}\right)<0$, then

$\left.P G=100 \times\left(A_{\text {test }}-A_{\text {tzero }}\right) / A_{\text {tzero }}\right)$

Where,

$\mathrm{A}_{\text {tzero }}=$ The average absorbance before exposure of cells to the test compound,

$A_{\text {test }}=$ The average absorbance after the desired period of time ( 72 hours),

$A_{\text {cont }}=$ The average absorbance after 72 hours with no exposure of cells to the test compound.

Each test point was performed in quadruplicate in minimum three individual experiments. The results are expressed as concentration-response graph. A negative percentage indicates cytotoxicity following drug treatment where $100 \%$ shows no cells survived the treatment at the specific drug concentration. The results are also expressed as growth inhibition of $50 \%\left(\mathrm{GI}_{50}\right)$, a concentration necessary for $50 \%$ of inhibition. Each result is a mean value from three separate experiments. The $\mathrm{GI}_{50}$ values for each compound are calculated from dose-response curves using linear regression analysis by fitting the test concentrations that give PG values above and below the respective reference value (e.g., 50 for $\left.\mathrm{GI}_{50}\right)$. Therefore, a "real" value for any of the response parameters was obtained only if at least one of the tested drug concentrations falls above, and likewise, at least one falls below the respective reference value. If, however, for a given cell line, all of the tested concentrations produce PGs exceeding the respective reference level of effect, then the lowest tested concentration is assigned as the default value. In screening data report, that default value is preceded by a "<" sign, signifying that the "real" value is something "less than" the lowest tested concentration. Likewise, if none of the tested concentrations produces the required PG reference level of effect or greater, then a ">" sign precedes the printed default value (which is the highest tested concentration), signifying that the "real" value is something "greater than" the highest tested concentration (13-15).

\section{RESULTS}

The yield of $L$. angustifolia essential oil was $2.25 \%$ $(\mathrm{v} / \mathrm{w})$ on dry weight basis. The oil was colorless with agreeable perfumery odor. A total of 25 compounds were identified, representing $98.2 \%$ of the total content of the essential oil (Table 2). The essential oil was dominated by the presence of alcohol (51.8\%) and ester derivatives $(22.6 \%)$, followed by monoterpene hydrocarbons $(11.0 \%)$, oxygenated monoterpenes $(5.5 \%)$, sesquiterpenes $(3.6 \%)$, and aliphatic compounds, which represent $4.0 \%$ of the total oil. Linalool was the most prominent compound found in highest concentration (37.9\%), followed by linalyl acetate $(12.1 \%)$ and lavandulyl acetate (8.3\%).

\section{Antibacterial activity}

The results of the antibacterial activity of the essential oils are presented in Table 1. Obtained results revealed that essential oil exhibited variable levels of antibacterial activity against all tested bacterial strains. The essential oils investigated showed better activity against Gram-positive than Gram-negative bacteria.

\section{Antioxidant activity}

This study, also, determined the antioxidant activity of one species of the family Lamiaceae. The results indicate that the hexane extract of the plant demonstrated antioxidant activity and showed the high activity with an $\mathrm{EC}_{50}$ value of $0.421 \mathrm{mg} / \mathrm{ml}$ (Table 3 and Figure 1).

\section{Antiproliferative effects of the essential oil}

The essential oil showed significant antiproliferative activity against three cancer cell lines, MOLT-4, 
TABLE 2. Chemical composition of Lavanda angustifolia essential oil

\begin{tabular}{|c|c|c|c|}
\hline Component & $\begin{array}{c}\mathrm{RT} \\
\text { (minutes) }\end{array}$ & RI & Percent \\
\hline Monoterpene hydrocarbons & & & 11.0 \\
\hline a-Thujene & 5.24 & 929 & 0.1 \\
\hline a-Pinene & 5.44 & 938 & 0.2 \\
\hline Camphene & 5.85 & 955 & 0.1 \\
\hline Myrcene & 6.78 & 990 & 0.9 \\
\hline p-Cymene & 7.82 & 1028 & 0.6 \\
\hline Limonene & 7.96 & 1033 & 0.9 \\
\hline$\beta$-Phellandrene & 8.01 & 1035 & 0.5 \\
\hline cis- $\beta$-Ocimene & 8.1 & 1038 & 3.3 \\
\hline trans- $\beta$-Ocimene & 8.43 & 1049 & 4.4 \\
\hline Monoterpene alcohols & & & 51.8 \\
\hline Linalool & 10.19 & 1102 & 37.9 \\
\hline Lavandulol & 12.23 & 1166 & 3.8 \\
\hline Borneol & 12.56 & 1176 & 1.9 \\
\hline Terpinen-4-ol & 12.83 & 1183 & 4.9 \\
\hline a-Terpineol & 13.32 & 1196 & 2.8 \\
\hline Nerol & 14.26 & 1226 & 0.5 \\
\hline Oxygenated monoterpenes & & & 5.5 \\
\hline 1,8-Cineole & 8.1 & 1038 & 0.7 \\
\hline trans-Linalool oxide & 9.21 & 1074 & 1.6 \\
\hline cis-Linalool oxide & 9.72 & 1089 & 1.2 \\
\hline Camphor & 11.73 & 1152 & 0.4 \\
\hline Crypton & 13.04 & 1189 & 1.2 \\
\hline Cumenaldehyde & 14.89 & 1245 & 0.5 \\
\hline Monoterpene esters & & & 22.6 \\
\hline Linalyl acetate & 15.1 & 1251 & 12.1 \\
\hline Lavandulyl acetate & 16.23 & 1284 & 8.3 \\
\hline Neryl acetate & 18.7 & 1359 & 0.7 \\
\hline Geranyl acetate & 19.34 & 1378 & 1.4 \\
\hline Aliphatic compounds & & & 4.0 \\
\hline 1-Octen-3-ol & 6.51 & 981 & 0.6 \\
\hline 3-Octanone & 6.66 & 986 & 0.3 \\
\hline Hexyl acetate & 7.38 & 1012 & 0.8 \\
\hline 1-Octen-3-yl acetate & 10.33 & 1107 & 1.5 \\
\hline Hexyl butanoate & 13.14 & 1192 & 0.8 \\
\hline \multicolumn{4}{|l|}{$\begin{array}{l}\text { Sesquiterpene } \\
\text { hydrocarbons }\end{array}$} \\
\hline Caryophyllene & 20.7 & 1420 & 1.1 \\
\hline \multicolumn{4}{|l|}{ Oxygenated sesquiterpenes } \\
\hline Caryophyllene oxide & 25.68 & 1582 & 2.5 \\
\hline Total & & & 98.4 \\
\hline
\end{tabular}

L. angustifolia: Lavanda angustifolia, RT: Retention time

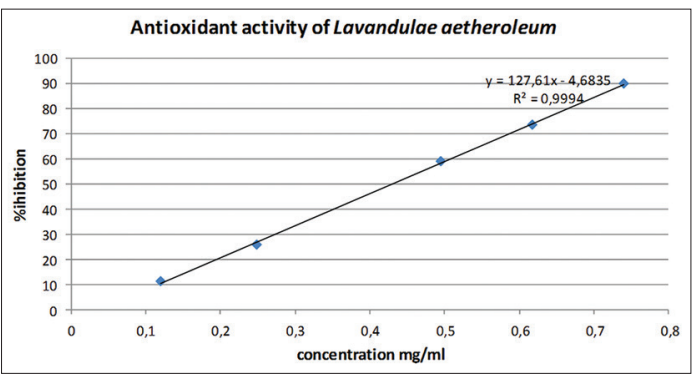

FIGURE 1. Reaction curve between $90 \mu \mathrm{M}$ 1,1-Diphenyl-2picrylhydrazyl and different solutions essential oil of Lavandula angustifolia.

NCI-H460 (H460), and MCF7, with inhibitory concentration $50 \%$ values of 17,94 , and $97 \mu \mathrm{g} / \mathrm{ml}$, respectively. GI of cells in vitro assessed by MTT assay 72 hours after the addition of essential oil (Figure 2) and doxorubicin (Table 4), presented as concentration-response profiles. Lavender oil was the most active on the acute lymphoblastic leukemia cells $\left(\mathrm{GI}_{50} 17 \mu \mathrm{g} / \mathrm{ml}\right)$. Less activity was found when lavender essential oil was applied to MCF7 and NCI-H460 cell cultures, $\mathrm{GI}_{50} 94 \mu \mathrm{g} / \mathrm{ml}$ and $\mathrm{GI}_{50} 97 \mu \mathrm{g} / \mathrm{ml}$, respectively.

\section{DISCUSSION}

We investigated composition, antiproliferative, and antimicrobial characteristics of $L$. angustifolia.

The most abundant components in oil were linalool (37.9\%), linalyl acetate (12.1\%), and lavandulyl acetate $(8.3 \%)$, whith the yield of $2.25 \%(\mathrm{v} / \mathrm{w})$. Other major constituents $(>1.0 \%)$ of the oil were lavandulol (3.8\%), terpinen 4 -ol (4.9\%), $\alpha$-terpineol $(2.8 \%)$, caryophyllene oxide $(2.5 \%), \beta$-caryophyllene $(1.1 \%)$. Characterized by its high content in linalool/linalyl acetate, this essential oil belongs to Mediterranean chemotype (16). Minor components $(<1.0 \%)$ identified in the oil were 1.8 cineole $(0.7 \%)$, limonene $(0.9 \%)$, camphor $(0.4 \%)$, and 3 -octanone $(0.3 \%)$. These components are important for evaluation of quality lavender oil according to European Pharmacopoeia. The concentrations of linalool, lavandulol, 1.8 cineole, limonene, camphor, terpinen-4-ol, and 3-octanone were in the range of European Pharmacopeia (17). However, recent studies of lavander oil composition from 
TABLE 3. Percentage of neutralization of DPPH • of essential oil of $L$. angustifolia

\begin{tabular}{lcccccc}
\hline \multicolumn{7}{c}{ Lavandulae aetheroleum } \\
\hline Concentration $(\mathrm{mg} / \mathrm{ml})$ & 0.12 & 0.249 & 0.495 & 0.617 & 0.74 & $\mathrm{IC}_{50}$ \\
$\%$ inhibition & 11.41 & 25.86 & 59.1 & 73.8 & 89.83 & $0.421 \pm 0.03$ \\
\hline
\end{tabular}

$\mathrm{IC}_{50}$ : Inhibitory concentration 50\%, L. angustifolia: Lavanda angustifolia, DPPH: 1,1-diphenyl-2-picrylhydrazyl

TABLE 4. $\mathrm{Gl}_{50}$ values (in $\mu \mathrm{g} / \mathrm{ml}$ )

\begin{tabular}{lccc}
\hline \multicolumn{3}{c}{$\mathrm{GI}_{50}{ }^{a}(\mu \mathrm{g} / \mathrm{ml})$} & \\
\hline Compound & \multicolumn{3}{c}{ Cell lines } \\
\cline { 2 - 4 } & $17 \pm 5$ & $\mathrm{MCF}-7$ & $\mathrm{H} 460$ \\
\hline Lavandulae aetheroleum & $0.02 \pm 0.01$ & $94 \pm 41$ & $97 \pm 43$ \\
Doxorubicin & $(0.003 \pm 0.002 \mu \mathrm{M})$ & $0.08 \pm 0.03$ & $0.03 \pm 0.01$ \\
& & $(0.15 \pm 0.04 \mu \mathrm{M})$ & $(0.05 \pm 0.01 \mu \mathrm{M})$ \\
\hline
\end{tabular}

${ }^{a} \mathrm{GI}_{50}:$ The concentration that causes $50 \%$ growth inhibition, as assessed by MTT assay, 72 hours after the addition of the test substances. MTT: 3-(4,5-dimethylthiazol-2-YI)-2,5-diphenyltetrazolium bromide

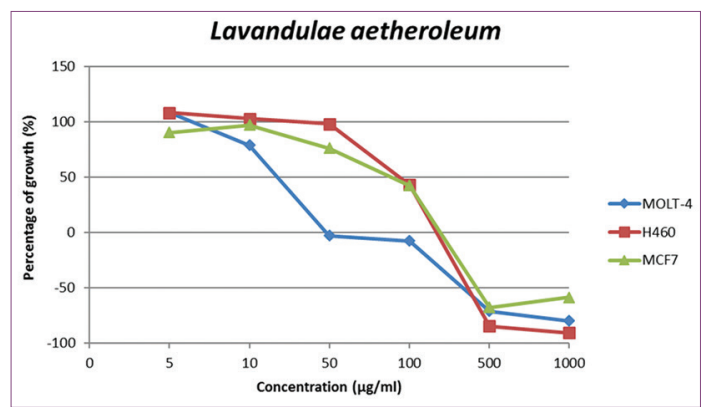

FIGURE 2. Growth inhibition of MOLT-4, NCl-H460 (H460) and MCF7 cells in vitro, assessed by 3-(4,5-Dimethylthiazol-2-YI)-2,5diphenyltetrazolium bromide assay 72 hours after the addition of lavender essential oil.

different regions showed that composition of major components may vary, e.g. linalool (27.3-42.2\%), linalyl acetate $(27.2-46.6 \%)$, trans $\beta$-ocimene (0.2-11.6\%), terpinen-4-ol (0.70-4.6\%), lavandulyl acetate $(0.50-4.8 \%), \quad \beta$-caryophyllene $(1.8-5.1 \%)$, cis $\beta$-ocimene $(0.30-3.8 \%)$, $\alpha$-terpineol $(0.30-2.0 \%)$, and 1,8 -cineole $(0.10-1.2 \%)(18,19)$. In our study the concentrations of lavandulyl acetate were higher while the linalyl acetate was lower. The differences observed in the constituents of essential oil in this study may be due to different chemotypes and environmental factors. Linalool, linalyl acetate, $\alpha$-terpineol, 1.8 cineole, terpineol 4-ol, limonene, and essential oils rich of these compounds possess various biological activities such as antiproliferative, antioxidant, and antimicrobial properties $(4,19)$.
The results of the antibacterial activity of the essential oils are presented in Table 1. Different concentrations $(5 \%, 1 \%$, and $0.5 \%)$ of the essential oils tested by disc diffusion method showed bacteriostatic activity on all bacterial stains, except $E$. coli. The essential oils investigation showed better activity against Gram-positive than Gram-negative bacteria. Most sensitive bacterial stains were $S$. aureus and $S$ epidermidis. According to literature, monoterpene alcohol linalool as other alcohols present, demonstrate high antibacterial activity $(7,20)$. Generally, hydrocarbon monoterpenes show the lowest antibacterial activity, while oxygenated compounds show a higher activity in general. Results also showed that greater antimicrobial potential could be assigned to oxygenated terpenes, especially the alcohol compounds $(20,21)$.

The results of the antiproliferative activity suggested that $L$. angustifolia essential oil inhibits the proliferation of MOLT-4, MCF-7, and H460 cells in a dose-dependent manner. Essential oil shows different activity toward tested cell lines. Interestingly, the lavender essential oil had the most anfiproliferative effect towards the MOLT- 4 cell line, GI $17 \mu \mathrm{g} / \mathrm{ml}$. Each type of cancer involves a specific signaling pathway. Moreover, an anticancer compound does not necessarily treat all types of cancer (22).

Together with antiproliferative, lavender oil showed antioxidant and antimicrobial properties (Tables 1, 3, 4). Even though there is a relationship between these three activities, the different 
mechanisms, involving different compounds present in essential oil, could explain existence of these various effects. Indeed, ROS may interact with and modify cellular protein, lipid, and DNA, which results in altered target cell function. The accumulation of oxidative damage has been implicated in both acute and chronic cell injury, including possible participation in the formation of cancer (22). A link between infection and cancer has long been suspected, but its molecular nature remained still to be defined (23). Chronic infection may directly affect the cells that eventually become transformed as well as exert indirect effects on the tumor cell through surrounding cells $(24,25)$. In literature, comparative studies of cytotoxic and apoptotic properties of the essential oil of $L$. angustifolia on malignant cells showed that lavender essential oil was effective against MCF-7 and HeLa cell lines (26). Furthermore, another study on lavender essential oil from Morocco confirmed antiproliferative activity on MCF-7 line cells $\left(\mathrm{GI}_{50} 98.5 \mu \mathrm{g} / \mathrm{ml}\right)$ (27). Comparing results obtained from the similar study undertaken from different geographical regions showed similar antiproliferative activity on MCF-7 cell line.

In this work and in the available literature, lavender essential oil seems to have a potential as anticancer therapeutic agents. However, the presence of the phytocomplex of numerous constituents that simultaneously interfere with multiple signaling pathway might be reason for effective anticancer therapy.

\section{CONCLUSION}

The results of our study suggest that the essential oil of $L$. angustifolia has potential antiproliferative activity against several malignant cell lines (MOLT-4, MCF-7, and H460), with the biggest effect shown on hematological malignant MOLT-4 cells. In addition, antioxidant and antimicrobial properties were observed, which were found to correlate with the level of mainly monoterpene alcohols and esters. However, further research is required to elucidate the exact mechanism of action, as well as to determine the safety of the long-term use.

\section{CONFLICT OF INTEREST}

The authors declare no conflict of interest.

\section{REFERENCES}

1. Ferlay J, Soerjomataram I, Dikshit R, Eser S, Mathers C, Rebelo M, et al. Cancer incidence and mortality worldwide: Sources, methods and major patterns in GLOBOCAN 2012. Int J Cancer 2015;136(5):E359-86.

2. Cancer. World Health Organization. Available from: http://www.who.int/ mediacentre/factsheets/fs297/en. [Accessed on 2017 Feb 17].

3. Plummer M, de Martel C, Vignat J, Ferlay J, Bray F, Franceschi S. Global burden of cancers attributable to infections in 2012: A synthetic analysis. Lancet Glob Health 2016;4(9):e609-16. https://doi.org/10.1016/S2214-109X(16)30143-7.

4. Sobral MV, Xavier AL, Lima TC, de Sousa DP. Antitumor activity of monoterpenes found in essential oils. ScientificWorldJournal 2014;2014:953451. https://doi.org/10.1155/2014/953451.

5. Bayala B, Bassole IH, Gnoula C, Nebie R, Yonli A, Morel L, et al. Chemical composition, antioxidant, anti-inflammatory and anti-proliferative activities of essential oils of plants from Burkina Faso. PLoS One 2014;9(3):e92122. https://doi.org/10.1371/journal.pone.0092122.

6. Bozin B, Mimica-Dukic N, Simin N, Anackov G. Characterization of the volatile composition of essential oils of some Lamiaceae spices and the antimicrobial and antioxidant activities of the entire oils. J Agric Food Chem 2006;54(5):1822-8. https://doi.org/10.1021/jf051922u.

7. Sokovic M, Glamoclija J, Marin PD, Brkic D, van Griensven LJ. Antibacterial effects of the essential oils of commonly consumed medicinal herbs using an in vitro model. Molecules 2010;15(11):7532-46. https://doi.org/10.3390/molecules15117532.

8. Husain IA. Characterization and Biological Activities of Essential Oi of Some Species of Lamiaceae (PhD Thesis). Faisalabad, Pakistan: University of Agriculture; 2009. p. 43-53.

9. Council of Europe European (COE). European Pharmacopeia. $7^{\text {th }}$ ed. Strasbourg, France: Cedex; 2010. p. 183-4.

10. Adams RP. Identification of Essential Oil Components by Gas Chromatography/Mass Spectroscopy. Illinois: Allured Publishing; 2007. p. 469.

11. Niksic H, Kovac-Besovic E, Makarevic E, Duric K. Chemical composition, antimicrobial and antioxidant properties of Mentha longifolia (L.) Huds. Essential oil. J Health Sci 2012;2(3):192-200. https://doi.org/10.17532/jhsci.2012.38.

12. Proestos C, Lytoudi K, Mavromelanidou OK, Zoumpoulakis $P$ Sinanoglou VJ. Antioxidant capacity of selected plant extracts and their essential oils. Antioxidants (Basel) 2013;2(1):11-22. https://doi.org/10.3390/antiox2010011.

13. Sylvester PW. Optimization of the tetrazolium dye (MTT) colorimetric assay for cellular growth and viability. Methods Mol Biol 2011;716:157-68. https://doi.org/10.1007/978-1-61779-012-6_9.

14. National Cancer Institute Welcome to the Developmental Therapeutics Program. In: Developmental Therapeutics Program (DTP). Available from: https://www.dtp.cancer.gov. [Accessed on 2016 Feb 17].

15. Boyd MR, Kenneth DP. Some practical considerations and applications of the national cancer institute in vitro anticancer drug discovery screen. Drug Dev Res 1995;34(2):91-109. https://doi.org/10.1002/ddr.430340203.

16. Zouari N. Essential oils chemotypes: A less known side. Med Aromat Plants 2013;2(2):145.

17. Council of Europe European (COE). European Pharmacopeia. $5^{\text {th }}$ ed. Strasbourg, France: Cedex; 2005. p. 1894-5.

18. Singh $P$, Andola $H$, Rawat $M$, Pant GJ, Jangwan JS. GC-MS analysis of essential oil from Lavandula angustifolia cultivated in Garhwal Himalaya. Nat Prod J 2015;5:268-72. https://doi.org/10.2174/2210315505666150908232137.

19. Jeon DH, Moon JY, Hyun HB, Cho SK. Composition analysis and antioxidant activities of the essential oil and the hydrosol extracted from 
Rosmarinus officinalis L. and Lavandula angustifolia Mill. produced in Jeju. J Appl Biol Chem 2013;56(3):141-6. https://doi.org/10.3839/jabc.2013.023.

20. Herman A, Tambor K, Herman A. Linalool affects the antimicrobial efficacy of essential oils. Curr Microbiol 2016;72(2):165-72. https://doi.org/10.1007/s00284-015-0933-4.

21. Passalacqua NG, Tundis R, Upson TM. A new species of Lavandula sect. Lavandula (Lamiaceae) and review of species boundaries in Lavandula angustifolia. Phytotaxa 2017;292(2):161. https://doi.org/10.11646/phytotaxa.292.2.3.

22. Manosroi J, Dhumtanom P, Manosroi A. Anti-proliferative activity of essential oil extracted from Thai medicinal plants on KB and P388 cell lines. Cancer Lett 2006;235(1):114-20. https://doi.org/10.1016/j.canlet.2005.04.021.

23. AverySV.Oxidativestressandcellfunction. In:Laherl,editor.SystemsBiology of Free Radicals and Antioxidants. Vancouver: Springer; 2014. p. 89-112. https://doi.org/10.1007/978-3-642-30018-9_3.
24. Mierke CT. The fundamental role of mechanical properties in the progression of cancer disease and inflammation. Rep Prog Phys 2014;77(7):076602. https://doi.org/10.1088/0034-4885/77/7/076602.

25. Tanno T, Matsui W. Stem cell theory and inflammation-related cancer. In: Hiraku $\mathrm{Y}$, Kawanishi $\mathrm{S}$, Ohshima $\mathrm{H}$, editors. Cancer and Inflammation Mechanisms: Chemical, Biological, and Clinical Aspects. Hoboken: John Wiley \& Sons, Inc.; 2014 . p. 9-22. https://doi.org/10.1002/9781118826621.ch2.

26. Tayarani-Najaran Z, Amiri A, Karimi G, Emami SA, Asili J, Mousavi $\mathrm{SH}$. Comparative studies of cytotoxic and apoptotic properties of different extracts and the essential oil of Lavandula angustifolia on malignant and normal cells. Nutr Cancer 2014;66(3):424-34. https://doi.org/10.1080/01635581.2013.878736.

27. Imelouane B, El Bachiri A, Wathelet JP, Dubois J, Ahmadi H. Chemical composition, cytotoxic and antioxidant activity of the essential oil of Lavandula dentate. World J Chem 2010;5:103-10. 